\title{
RETAIL BUSINESS IN AN EMERGING ECONOMY: THE CASE OF VIETNAM
}

\author{
by Trinh Thuy Anh ${ }^{1}$ - Tran Tuan Anh
}

\begin{abstract}
In the recent decades, emerging economies have developed rapidly attracting foreign direct investment and advanced services, especially in the retail business sector. This research paper aims to point out the trend of retail business in a Southeast Asian emerging country, Vietnam. Retail business in Vietnam is more attractive due to its young population occupying 65\% of the national population who maintain optimistic shopping behaviors. Since 2008, the negative impact of the global financial crisis and Vietnam's economic instability have affected the Vietnam's retail market negatively. It seems that potential retail market is on the decrease when the attractive index of the retail market was number one in 2008, number sixth in 2009 and number fourteen in 2010 in the world. This research assesses whether an emerging economy like Vietnam would continue to be an attractive destination for international retail market and what deterred big retailers from investing in Vietnamese market? Furthermore, are local retail businesses ready for competition? If so, what is the current trend in a rapidly changing and risky environment as Vietnamese economy is experiencing at the moment.

This research employs integrated statistical comparison and analysis. Demand and supply model in retail business is employed to identify the trend of retail business in Vietnam. Furthermore, this paper proposes strategies for retail business development in Vietnam in order to refocus the role of government to support the development of retail business.

Our assessment suggests that Vietnamese businesses which utilize modern business concepts have grown swiftly while local businesses that follow traditional retail channel are under increased pressure for change due to market competition. The urban market remains attractive to domestic and foreign investors while the rural market is largely unexplored. Consequently, a combination between modern and traditional concepts could be utilized to promote and exploit full potentials of Vietnam's retail business. This adaptation, which requires businesses to shift from traditional concepts into modern concepts, demands drastic change in business modeling such as size, structure and business practices. The research also provides policy suggestions including improvement of facility development, refining local supply chain, and simplifying procedural logistics for businesses to help them smoother this transition.
\end{abstract}

Keywords: retail, Viet nam, emerging economy 


\section{OVERVIEW OF VIETNAM RETAIL BUSINESS}

The process of global economic integration in Vietnam has been widely and deeply impacting on many economic fields. Particularly, the retail business is one of the fields which develops more dynamically and has more developing potentials. In the past decades, Vietnam's economy has achieved high growth rates comparing with these of other developing countries. Thus, life quality of the people has been increasingly improved. Thanks to increasing income, consumer demand increases every year, creating conditions for the retail business to stably develop. In the period of 20062009 , average growth rate of the retail market was about $22 \%$ annually. Total domestic retail sales in 2010 reached 77.8 billion dollars which is more than $70 \%$ GDP of the country. This number is higher than that of other countries in the region (the percentage of retail sales is $55.9 \%$ in Singapore, $58.2 \%$ in Malaysia and $67.7 \%$ in Thailand).

\section{Figure 1. Total retail trade in the period 2005-2010 (Billion USD)}

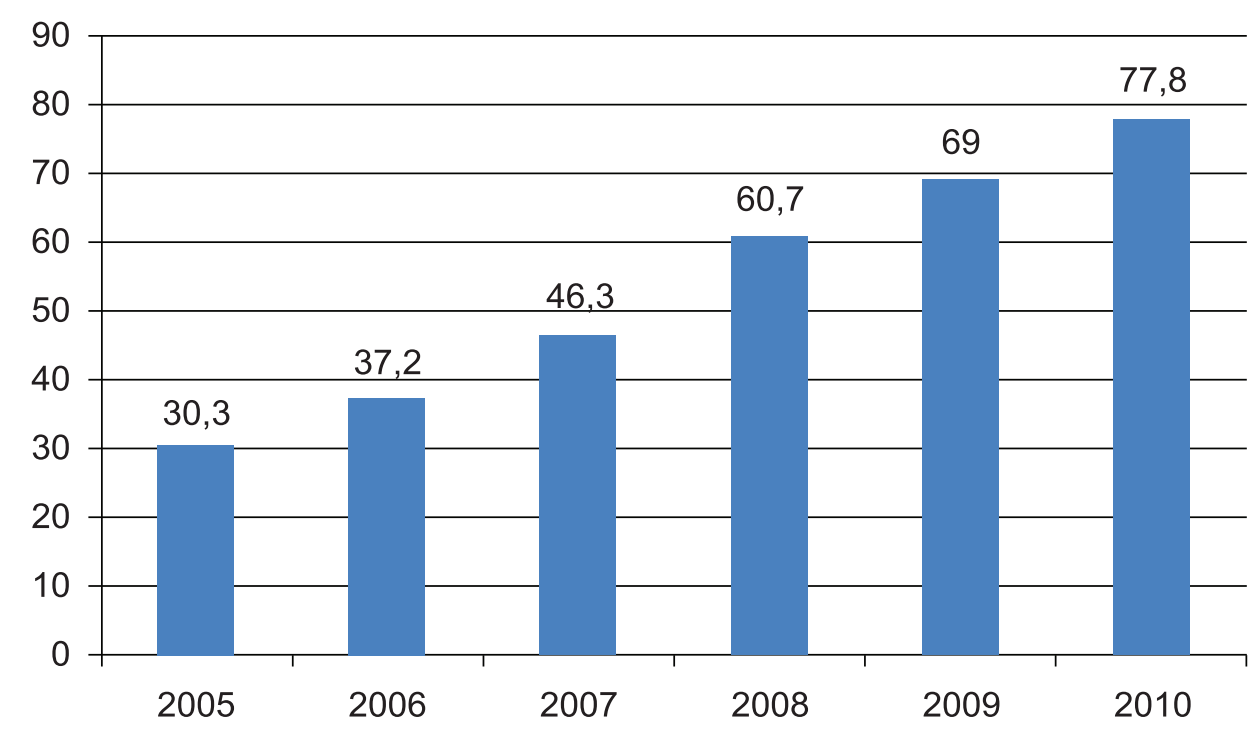

Source: Vietnam General Statistics Office

Besides the growth in sales, retail types in Vietnam have been rapidly changing. In the past, the common type in retail business was traditional markets and small individual shops. Now, modern forms of retailing institution such as supermarkets, shopping centers, special stores, convenience stores are gradually formed, rapidly growing alongside the development of traditional forms. The growth of modern type of retail institution has been promoting the development of retail business in Vietnam. Moreover, since Vietnam integrated into the global economy through WTO (World Trade
Organization) commitments, many new factors have appeared to promote the development of the retail sector in the country. The foreign-invested enterprises are penetrating and expanding business in Vietnam, creating favorable conditions to the retail sector to more develop and be more competitive: competition between traditional retail forms and modern retail forms, competition between foreign and domestic retail businesses. The formation and development of modern retail forms marked the growth of the retail business in Vietnam recently, especially in big cities such as Ho Chi Minh city and Hanoi. 
Many strong domestic retailer brands have quickly dominated the retail business. The most prominent was the formation and growth of supermarkets as Co.opMart, Hapro Mart, Big C, Fivi Mart... Until late 2010, Co.opMart has had 50 supermarkets in the country; Meanwhile, Hapro Mart, owned by Hanoi Supermarket Joint Stock Corporation, has had 30 supermarkets; Fivi Mart has had 15 supermarkets; Big $\mathrm{C}$, foreign retail business, has established 14 supermarkets in major cities throughout the country. The presence of these supermarkets has been promoting the modernization trends in retail channels in Vietnam.

The growth in size and retail sales has taken many Vietnam retail businesses to the list of TOP retail businesses in Asia Pacific. Until 2010, Vietnam has had 10 retail companies which ranked in the TOP 500 retailers in Asia Pacific ranked by Retail Asia Magazine coordinating with market research firms KPMG and Euro monitor. Leading in the top of this list was Saigon Coop with the sales in 2009 reaching 498 million USD.

Besides the growth of supermarket trading daily necessary goods and consumer goods, specialty stores and convenience stores are also developed. Supermarkets that sell electronics, electrical appliances, telecommunication equipment such as Nguyen Kim chain, Best Caring's and Mobile World also ranked in the Top 500 big retail businesses in Asia Pacific. The success of those companies has confirmed the position of this type of retailing in Vietnam retail business.

Currentlyin Vietnam, the convenience store chain is actively expanding its distribution channel throughout big cities in the country. The biggest convenience store chain is G7 Mart with about 500 convenience stores. This kind of store has been quickly developing during the last few years. Many companies in Vietnam are investing to expand the convenience store, especially in big cities like Ho Chi Minh city and Hanoi.

Table 1. Types of retail business in Vietnam

\begin{tabular}{|c|c|c|c|c|c|}
\hline No & & Type & Unit & Total & Note \\
\hline \multirow{5}{*}{1} & \multirow{5}{*}{ Markets } & Total & Market & 8.173 & $\begin{array}{c}(31 / 12 / 07) \\
\text { aggregate }\end{array}$ \\
\hline & & Urban & market & 1.772 & $\begin{array}{c}21,7 \% \\
\text { proportion }\end{array}$ \\
\hline & & Rural & market & 6.401 & $\begin{array}{c}78,3 \% \\
\text { Proportion }\end{array}$ \\
\hline & & $\begin{array}{l}\text { Wholesale } \\
\text { markets of } \\
\text { agricultural } \\
\text { products }\end{array}$ & market & 92 & \\
\hline & & Retail & market & 8.081 & \\
\hline 2 & Shopping centers & & Center & 70 & $\begin{array}{c}\text { (estimated } \\
\text { number) }\end{array}$ \\
\hline 3 & Supermarkets & & Supermarket & 350 & \\
\hline
\end{tabular}




\begin{tabular}{|c|l|l|l|l|c|}
\hline 4 & $\begin{array}{l}\text { Small shops of } \\
\text { individual business } \\
\text { household }\end{array}$ & Shops & 900.000 & \\
\hline 5 & $\begin{array}{l}\text { Companies operating in } \\
\text { the retail sector }\end{array}$ & Company & 55.000 & $\begin{array}{c}2006 \\
\text { Survey data }\end{array}$ \\
\hline 6 & $\begin{array}{l}\text { Cooperative trade } \\
\text { service }\end{array}$ & Cooperative & 685 & $\begin{array}{c}\text { Aggregate } \\
31 / 12 / 2007\end{array}$ \\
\hline 7 & Household business & $\begin{array}{l}\text { Million } \\
\text { household }\end{array}$ & 2,9 & \\
\hline
\end{tabular}

Source: Ministry of Industry and Trade of Vietnam

The attractiveness of retail business in Vietnam is also expressed through the market rankings by A.T. Kearney. Within recent three years, Vietnam has always occupied a high rank in the ranking of attractive investment markets.

\section{WTO INTEGRATION PROCESS AFFECTING TO RETAIL BUSINESS}

From 11.01.2007, Vietnam officially became the $150^{\text {th }}$ member of the World Trade Organization. Since then, Vietnam has begun to implement the roadmap of WTO commitments. In the retail sector, as from 1.1.2009, Vietnam has allowed foreign investors to establish businesses with $100 \%$ foreign capital in the retail business. This commitment was an important step in opening up Vietnam retail industry. Supermarkets, shopping centers and other modern retail types with $100 \%$ foreign capital have penetrated into Vietnam retail market. However, as committed, to establish the second location or subsidiary, foreign investors must obtain the permission, comply with the criteria of geographical size, with number of retailers in the area, with the stability of the market, with population density in the locality and in accordance with the planning of local authority.

The process of international integration has enabled many big retail businesses around the world to penetrate into the Vietnam retail industry. Currently, some big enterprises are participating and expanding business in Vietnam such as Big C (France), Metro Cast Carry (Germany), Lotte (South Korea), Parkson (Malaysia). These enterprises mainly build and expand supermarkets and modern shopping centers. Besides, some foreign enterprises choose the strategy of business cooperation with local businesses like Minitop (Japan) - being a joint venture with G7 Mart to deploy convenience stores in Vietnam. Fair Price - one of the leading retail businesses in Singapore - is implementing cooperation projects with Coop Mart to expand the supermarket chain in some big cities in Vietnam.

The penetration of foreign corporation creates a new face for the retail industry in Vietnam recently. Retail corporations have invested more in retail infrastructure and in personnel training. This has changed the service style in the whole retail sector. A modern style and polite shopping environment is taking shape. The foreign retail enterprises have brought the modern trend of retail to Vietnam. This promoted the local retailers to invest more in retail business to have better competition. And this has brought more benefits to local consumers. In comparison with the past, supermarkets and shopping centers have 
had bigger scales now, and especially goods are more diversified. The sales technology has been invested towards computerization and automation, creating a modern environment in the retail service.

The coming of foreign retail enterprises created competitions, speeding up the development of local businesses. Many domestic enterprises such as CoopMart learnt from foreign corporations the experience of retail system management, and then applied modern business management in different fields such as sourcing and exploiting goods supplies and improving their marketing, sales, logistics, personnel management and retail operations. This is the inherent weak point of local supermarket systems that are in the phase of forming and developing. Some local supermarkets focus on their loyal customers. Lots of loyal customer care programs are implemented. Some supermarkets develop goods with their own brand name. This is a new trend in the Vietnam retail market while adopting modern retail technologies of the world. At the moment, own-brand names in fields of food, confectionery and washing substance have been in a trial period with some initial success.

Besides some positive effects, economic integration also brought to Vietnam retail enterprises some problems. Competitiveness between domestic and foreign retail companies are becoming more and more drastic, especially in big cities of Vietnam such as Ho Chi Minh city, Hanoi, Danang, Can Tho. With their advantages in capital, experience in developing emergent markets and modern retail technologies, foreign enterprises have many advantages entering Vietnam market. According to a research of Vietnam Retail Association, although having difficulties in approaching Vietnam market, foreign enterprises have their own initial success when entering. Vietnamese consumers rapidly adapt to professional trading environment and advanced business policies of foreign enterprises. Threat of losing market share to foreign enterprises is completely a possibility for local business in a near future.

Together with advantages and challenges to Vietnam retail industry in the process of global economic integration, difficulties in world economy recently had definite impacts on the market development.

\section{MACROECONOMIC FACTORS AFFECTING THE RETAIL MARKET \\ Global economic crisis recently has negatively affected the economic development of Vietnam. Growth rate of Vietnam GDP was high whereas that of other developing countries decreased in recent period.}

Figure 2. Growth rate of Vietnam GDP

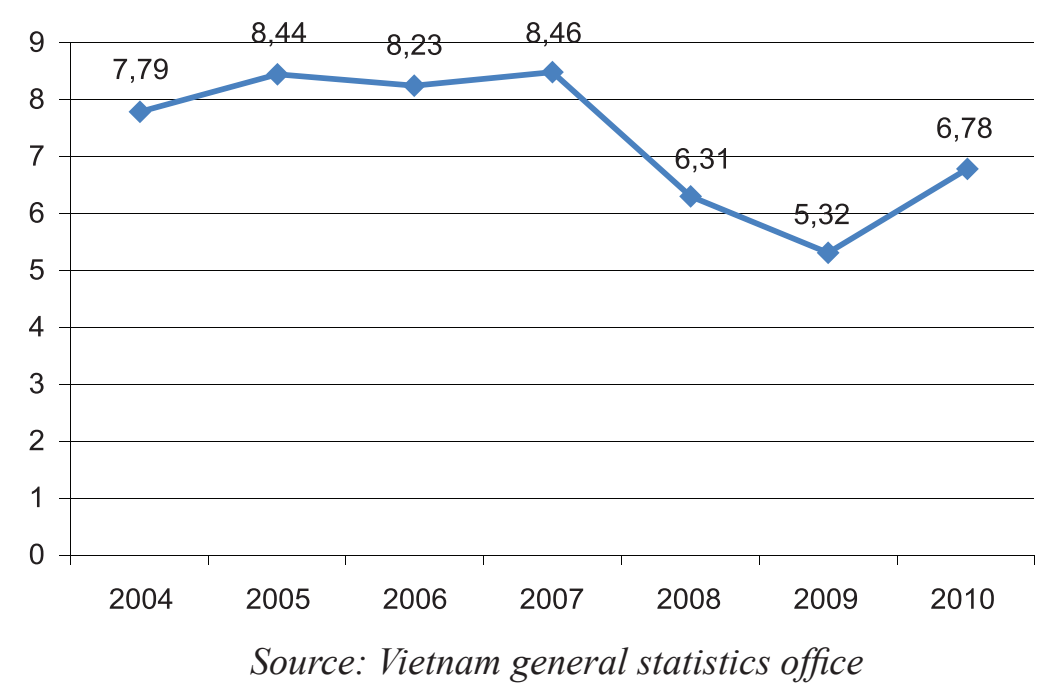


Vietnam economics has had many difficulties since 2008. Many measures to stimulate demands made by Vietnamese government in 2009 helped hold the decrease of GDP. However, the result was not as expected. Growth rate was 5.32\% in 2009. This was the least growth rate of Vietnam in the past 10 years of reforming and integrating into global economics. In the short term, Vietnam macroeconomics has many challenges from the changes of world economics.

After the shock of decrease in growth rate of GDP, Vietnam has been facing to the increase of inflation problem in recent years. In the beginning of 2010 ,
Vietnamese government had a target of keeping the increase of CPI under $7 \%$. However, in reality, this rate was $11.75 \%$, 1.8 times higher than that of previous year. High inflation decreased the purchasing power of the money and also decreased the living standard of people with average and low income who took the most of Vietnamese population.

Comparing Dec. 2010 with Dec. 2006, CPI of Vietnam increased $60.74 \%$. In the first five months of 2011, the increase speed of CPI was even higher, 12.07\% comparing with Dec. 2010 and $19.78 \%$ comparing with five months of the previous year.

Figure 3. Movements of the CPI 2009 and 2010 in Vietnam

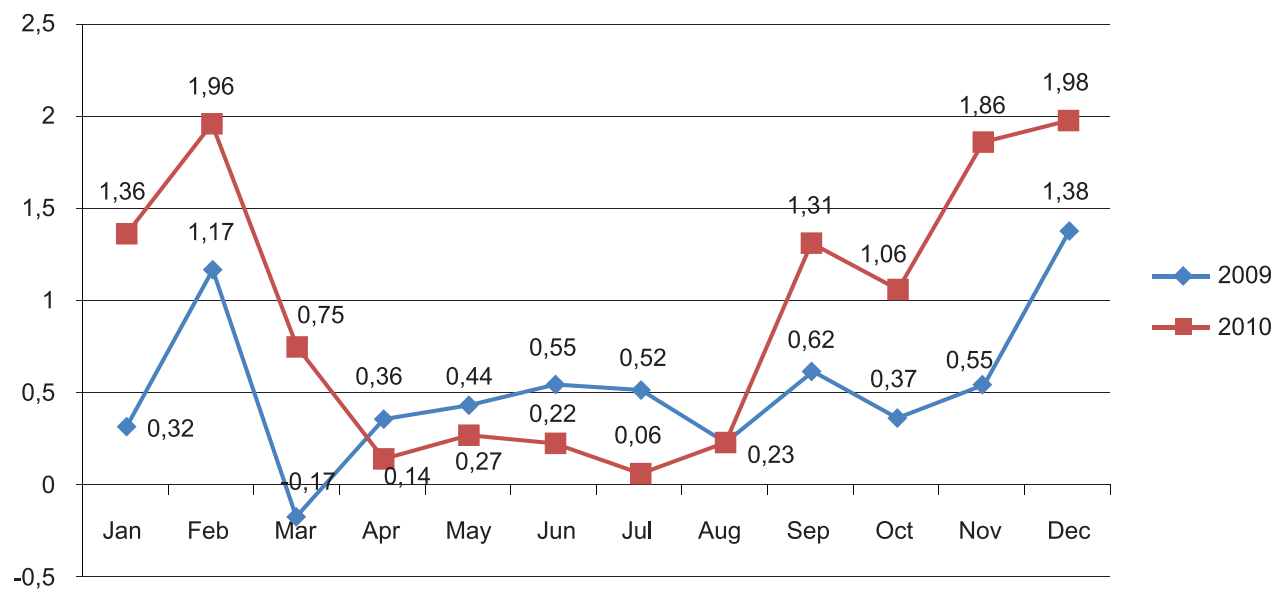

Source: Vietnam General Statistics office

One of the macroeconomic problems giving headache to businessmen, especially retailers and suppliers, is interest rate is at a high level. Since beginning of 2011, Vietnamese government has implemented monetary tightening policies, decreasing social investment and expenditure, decreasing cash circulation in the market in order to restrain inflation. Currently, bank loan interest is $23-25 \%$ per annum. This brings difficulties to enterprises in maintaining the manufacturing. Many enterprises have to reduce their manufacturing and retail enterprises have the same problems. According to the economic regulation policy of the government, this bank loan interest may be kept until the end of 2020. The increase in bank loan interest, cutting down non-production loan and discouraging consuming loan are now an obstacle in the development of Vietnam retail market, especially in installment credit.

Despite meeting difficulties in the process of WTO post-integration and negative impacts from the economics of Vietnam, the retail market still has chances to strongly develop. Core factors for the market development will be presented below. 
4. MAIN FACTORS STIMULATING THE RETAILBUSINESS DEVELOPMENT

Vietnam is a country whose economy is newly emergent and in the process of transition to market mechanisms. On natural aspect, there are many positive factors for the sustainable development of the market. The key factors to be mentioned are: disposable income, population structure, the consumer confidence index, the culture and consumer behavior and the growth of the Internet in Vietnam. We will examine in turn these factors.

\section{Disposable income}

It can be said that, the rapid economic growth rate of Vietnam in recent years has contributed significantly to increase people's income. GDP growth rate of Vietnam recently has maintained at a high level. Either during the world economic crisis in 2008 or in the recovery phase with current difficulties, GDP growth rate of Vietnam is always in the top of the fast-growing economies in the world.

Figure 4. Vietnam average income per capita (dollars) during 2001 - 2009

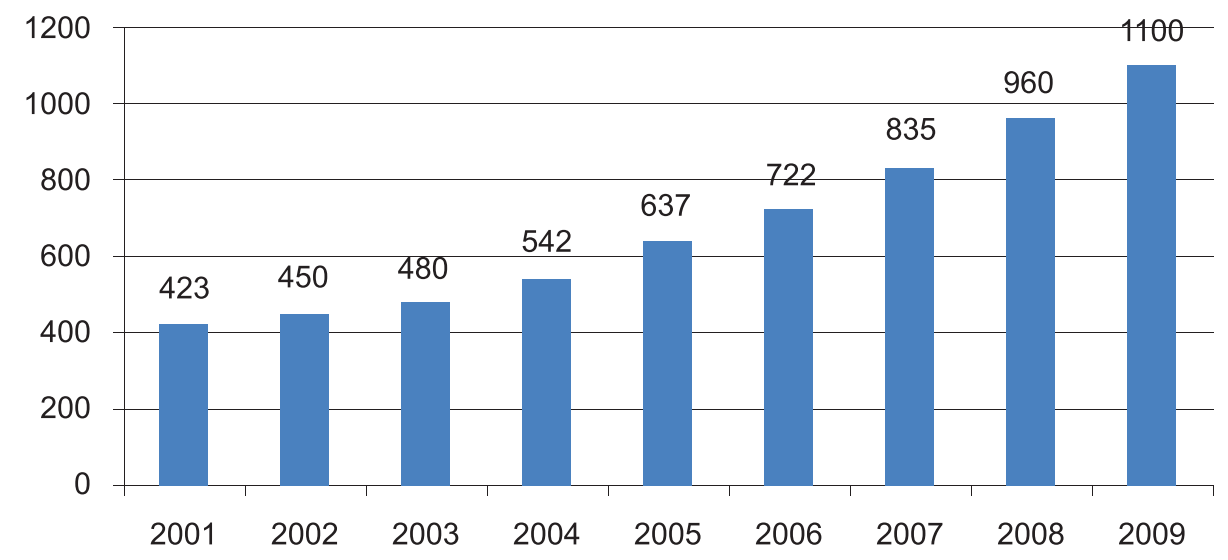

Source: Vietnam General statistics office

Thanks to the growth of GDP, the income of the population has increased almost 3 times during the past 10 years which has spurred the growth of personal consumption.

This has led to the increase of total retail sales. In 2010, the total retail sales reached about 77.8 billion dollars that was 4.7 times higher than that in 2001. Forecasting for the coming years, the growth rate of retail sales will be maintained about $25 \%$ annually.

\section{Population structure}

With a population of 86 million, Vietnam is one of the major markets in Southeast Asia. Moreover, in terms of population structure, Vietnam is in the period of gold population level with $60 \%$ of the population aging less than 35 years old. Young population structure is a good factor that affects the growth of the retail industry because young consumers have high demand in procurement and they adapt to various types of modern shopping. Furthermore, with about $72 \%$ of population that live in rural areas whose income have been improving, retail business have had a source of potential consumers with high purchasing power. Consumers in rural areas have accustomed to traditional retail types such as markets and small shops. This will promote the development of markets and small shops in rural areas in the near future. 
Figure 5. Vietnam population tower in $\mathbf{2 0 1 0}$

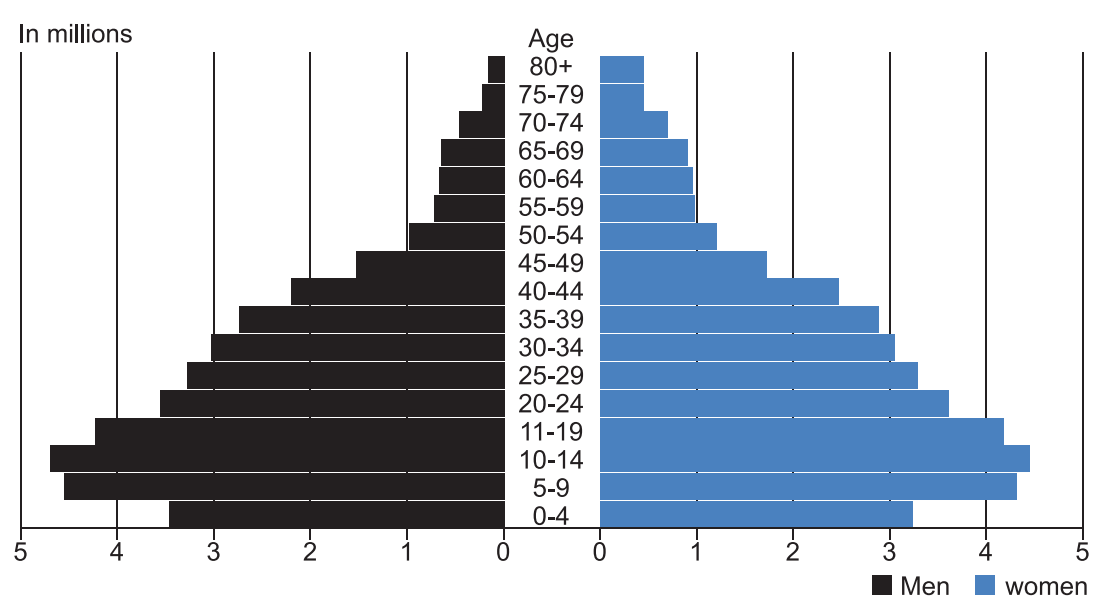

Source: Institute for population and social issues.

\section{Consumer confidence index}

Consumer confidence index affects the purchasing power of consumers. This index depends on many factors such as: prospects of economy, value of money, belief in employment, foreign investment and individual living standard. Consumer confidence index will affect positively the spending. This will lead to the improvement of consumers' buying power in the same income level.

Figure 6. Vietnam Consumer confidence index comparing with the world average consumer confidence index during 2006-2010

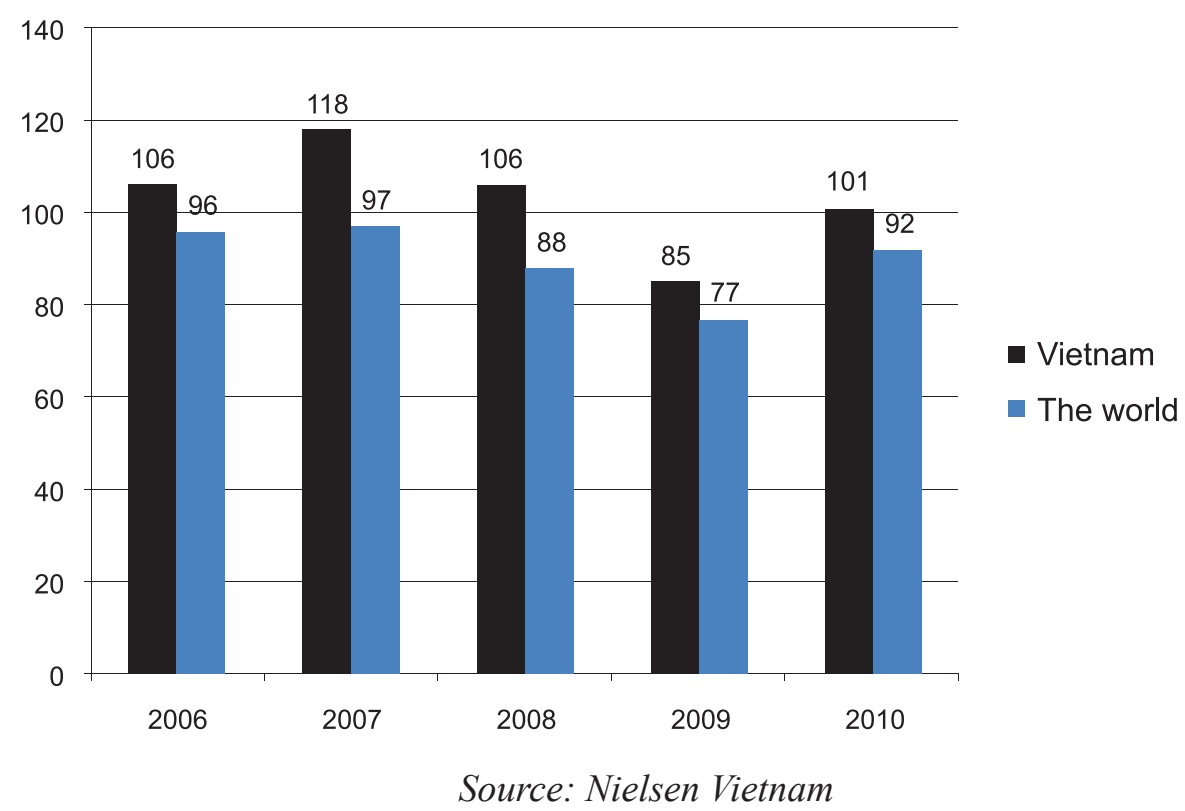

According to collective data of the last 5 years, the consumer confidence index of Vietnamese consumers is high to compare with the average index of the world, even in the period of global economic crisis, 2008 to 2010 . This is the positive indicator for the development of
Vietnam retail industry.

\section{Culture and consumer behavior}

Culture and consumer behavior affect the development of the retail market. Theoretically, the distribution of types of retailers should be tailored to culture 
and shopping behavior of consumers in residential area. The development of modern types of retail takes time to form and develop according to the adaption of local culture and consumer behavior. There was a lesson from the past about the improper retail types and consumer behavior. In the period 2002-2003, Masan Mart chain with 25 stores opened and quickly closed because the convenience stores were not a proper business model at that time. Consumers did not acquaint themselves with this kind of store. But since 2006, the situation has changed. There were many convenience stores thriving, mainly in big cities in Vietnam such as G7 mart chain, Shop \& Go chain. However, this type of retail is still in the stage of improving itself and adapting to culture and shopping behavior of Vietnamese consumers. In urban areas, with nearly $30 \%$ of the population, supermarkets and modern shopping centers take about $15-20 \%$ market share. Meanwhile, in rural areas, with $70 \%$ of the population, traditional retail types such as markets and household small shops take a bigger market share of about $90 \%$ because these still suit the culture and purchase behaviors of the people there.

Internet impacts and the potentials to develop e-commerce

Besides the characteristic of young population, the number of Internet users in Vietnam has recently increased. According to Vietnam Internet Center of the Ministry of Information and Communication, there are about 27 million internet users in Vietnam up to beginning of 2011. This means $31,5 \%$ of the population using Internet. This is an impressive figure for the developing of e-commerce.

Figure 7. Number of Internet users in Vietnam

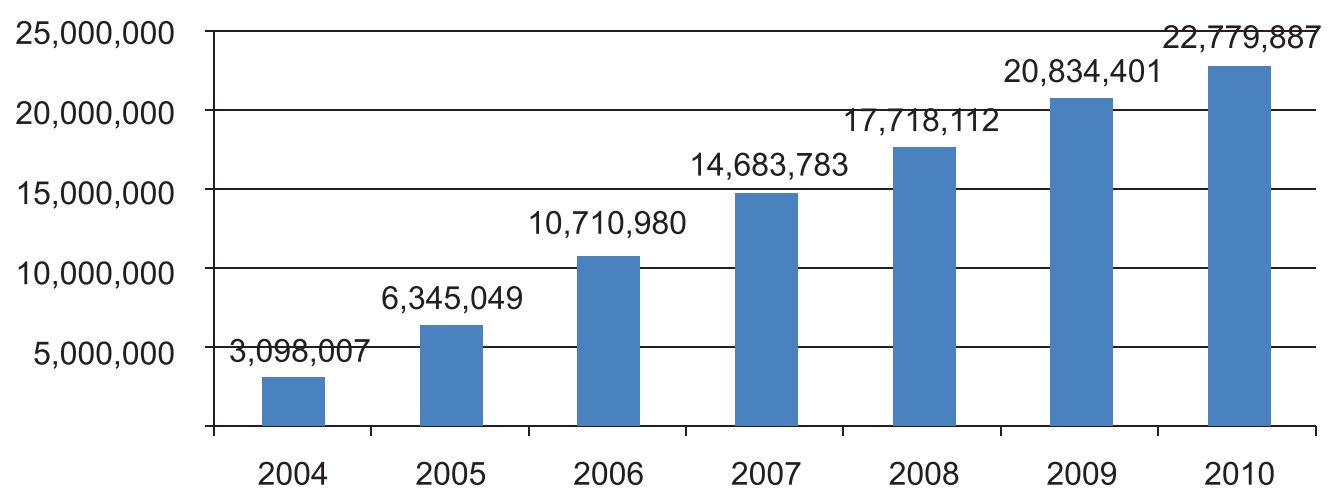

Source: Vietnam Internet center - Ministry of Information and Communication.

A recent research of Yahoo and Kantar Media made in 2009 showed that 97\% Vietnamese use Internet to read news. Those who use Internet to shop online take about $11 \%$. This is a very positive signal for the development of online shopping channel. However, due to restrain of infrastructure, the habit of using e-money or paying by credit cards is not yet popular in Vietnam. This restricts the development of this selling channel.
5. POLICIES TO PROMOTE THE GROWTH OF RETAIL BUSINESS IN VIETNAM

In order to maintain the growth rate of $22-25 \%$ in the coming period, Vietnam retail business needs favorable conditions. Through all above analysis, we can see that Vietnam retail market has potentials to strongly develop and can become one of the biggest retail markets in South East Asia. Nevertheless, since the 
time Vietnam officially opened its retail this market? A.T. Kearney evaluated market under WTO commitment, why big Vietnam as one among potential markets brands in retail business like Wal-Mart, according to Foreign Direct Investment Tesco, and Carrefour have not entered Confident Index.

\section{Figure 8. 2010 Foreign Direct Investments Confident Index}

\section{Foreign Direct Investment Confidence Index}

\section{Top 25}

(1) 1

(3) 2

(2) 3

(6) 4

(10) 5

(22) 6

(11) 7

(19) 8

(14) 9

(4) 11

(8) 12

(12) 13

(13) 14

(5) 15

(17) 16

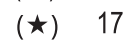

(25) 18

(9) 19

(*) 20

(21) 21

(16) 22

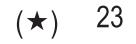

(20) 24

(17) 25

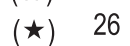

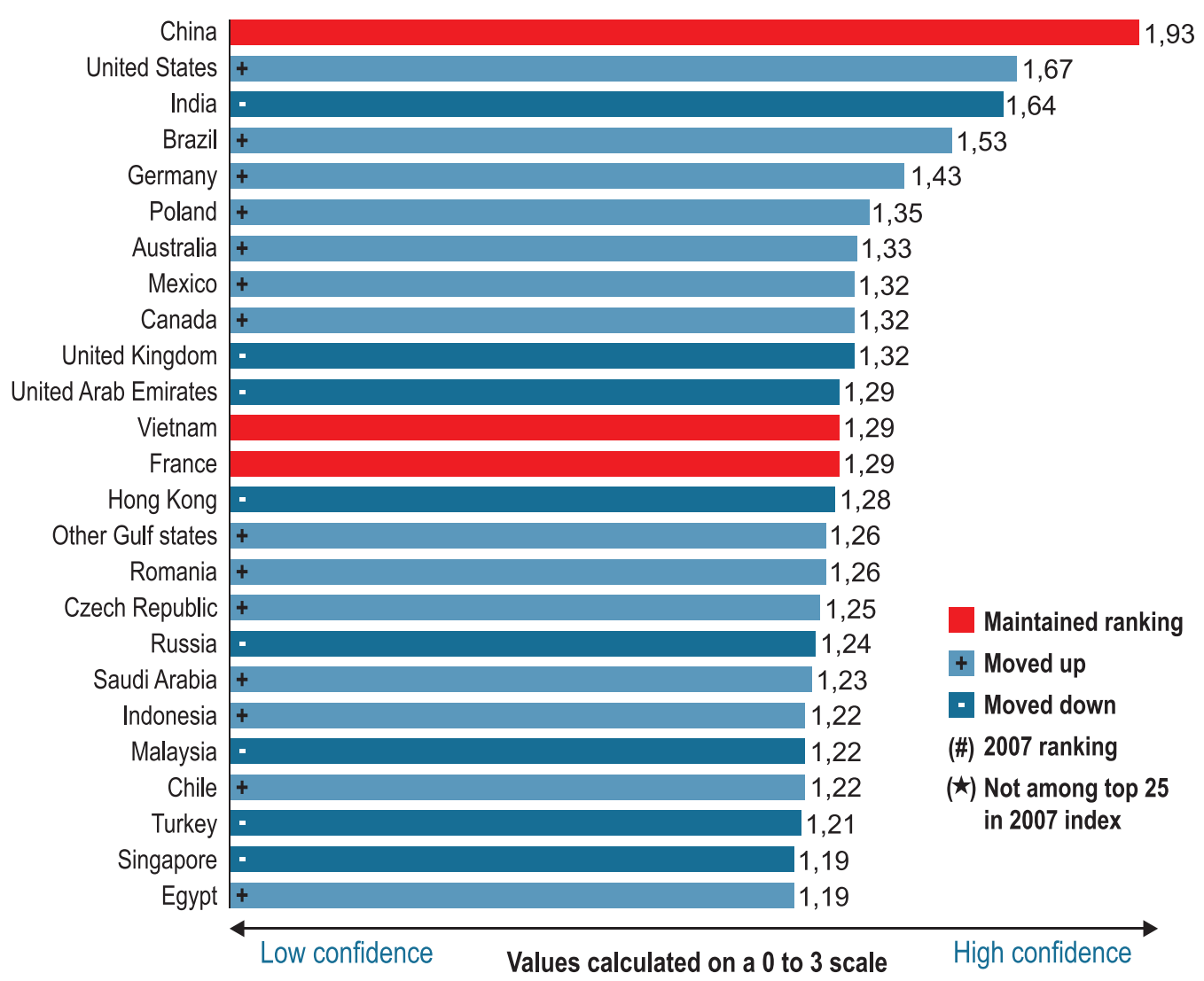

Source: A. T. Keerney analysis
One of the main reasons that the leading retail businesses worldwide have not entered Vietnam market is the size of the market. Only big cities such as Hanoi, HCMC, Da Nang, Can Tho are suitable for modern retail models like supermarket, hypermarket, shopping center. Other places have limited purchasing power.

Moreover, when opening the $2^{\text {nd }}$ retail outlet, foreign enterprises have difficulties to get permission from the authorities. The permission must be complied with local planning and with local requirements. The government needs to be explicit in legal system and administrative reform, giving favorable conditions to foreign business to invest in Vietnam retail market. Local authorities must continuously improve the retail industry planning and simplify administrative formalities, especially formalities for investment licenses. They must also give more detailed instructions in order that enterprises can approach and carry out the investment projects.

Vietnam retail market is a potential market with a population of about 86 million. However, about 60.4 million people (70.4\% of the population) live in rural areas. This sector needs to be planned for the development of distribution channel in accordance with the specific characteristic of the residents. Up to 2020, traditional 
retail forms will still remain and develop in rural areas. Therefore, the government should create good conditions to plan the development of markets coordinating with modern retail forms such as supermarket and shopping centers. This then can give ways to the development of retail markets in these areas.

One modern form of shopping having been established in Vietnam is e-commerce. Although Internet growth rate in Vietnam has recently increased remarkably, e-commerce is not yet developed. Many reasons lead to this slackness. One main reason is the lack of legal regulations for e-commerce development. Most enterprises implementing e-commerce in Vietnam have difficulties in payment system. Until the end of 2009 , the rate of credit card payment is only $1 \%$ out of total expenditure in Vietnam. Today, Vietnam is still lack of legal regulations on the rights of both enterprises and consumers in e-commerce. These obstacles must be overcome for the development of e-commerce.

\section{CONCLUSION}

Vietnam retail industry has played an important role and involvement to the economy development during the integration process into the world economy. The growth rate of this market is always high and stable. In the coming period, forecasted by experts, this growth rate will be maintained $20 \%$ per annual. In accordance to the market development, forms of retail business will change conformable to consumers' buying behaviors. Modern retail types such as supermarkets, shopping centers and specialty stores will be developed in parallel with traditional forms. Foreign retail business will penetrate and expand retail channel in Vietnam, creating competitive environment in retail industry. Today, Vietnam is facing some difficulties from macroeconomics such as high inflation and decline of economic growth. These factors have negative impacts on the market development. However, being a developing country with a big and young population who has high demand of consumption, retail industry still have lots of development potentials. In order to maintain this growth, the government must play a supportive role with suitable policies, especially for e-commerce, rural markets and advantage environment to help retail business develop firmly.

\section{REFERENCES}

1. Vietnam Industry and Trade Information Center, Ministry of Industry and Trade of Vietnam, 2010, "Hàng Việt vì nhu cầu thị hiếu tiêu dùng người Việt", Industy and Trade Publisher.

2. Vietnam Industry and Trade Information Center, Ministry of Industry and Trade of Vietnam, 2010, "Kinh nghiệm xúc tiến thương mại thị trường nội địa một số nước trên thế giới", Industy and Trade Publisher.

3. Vietnam Industry and Trade Information Center, Ministry of Industry and Trade of Vietnam, 2010, "Thị trường nội địa, tiềm năng còn bỏ ngõ", Industy and Trade Publisher.

4. http://www.gso.gov.vn

5. http://vinanet.com.vn/

6. http://retailasiaonline.com/

7. http://www.atkearney.com 